\title{
Forestry graduate programs and research funding in Canadian universities
}

\author{
by John A. McLean ${ }^{1}$
}

The qualifications for professional foresters in Canada are based on baccalaureate programs that meet national accreditation standards set out by the Canadian Forestry Accreditation Board (CFAB). Students who complete these programs, plus a period of usually two years in the field mentored by a professional forester and pass a provincial policy examination, may then become a registered professional forester in the province of their choice. There are seven schools in Canada that currently meet CFAB accreditation standards and these schools have recently been detailed by Luckai (2002). Together with the University of Toronto's Faculty of Forestry, these schools are members of the Association of University Forestry Schools of Canada (AUFSC). The faculty members who instruct in these programs are generally required to engage in research and the training of graduate students - the highly qualified personnel that will continue the quest for the improved knowledge needed to manage our extensive national forest heritage to the highest standards of sustainable forest management. Earlier versions of curricula concentrated on measuring the volume of trees on the landscape and designing the most cost-effective ways to move these logs to sawmills and pulp mills across the land. In the new millennium there is a requirement to manage the forest- ed landscape for the full range of values and products that they contain or protect as described for the programs at the University of Northern British Columbia by Dewhurst and Kessler (1999).

Forestry schools in Canada have developed a series of programs to meet graduate student needs in their areas. In order to attract students some faculties have extended or changed their names but all

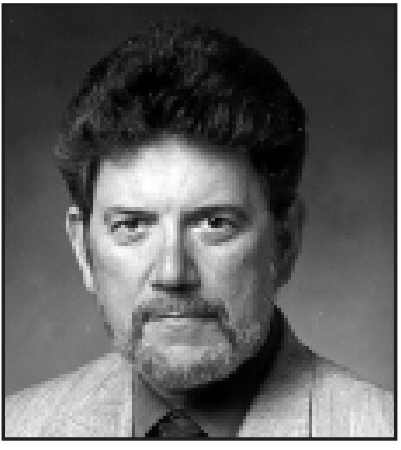

John A. McLean emphasize the multidisciplinary nature of forestry in the $21^{\text {st }}$ century. In the AUFSC schools, the University of Toronto no longer teaches an undergraduate program for professional foresters. The Faculty of Forestry at the University of Moncton in Edmundston was given Faculty status in September 2000 and presently offers a Master of Science research degree. Lakehead University's Faculty of Forestry and the Forest Environment offers the masterate programs, Master of Science

\begin{tabular}{|c|c|c|c|c|c|c|c|c|c|c|}
\hline \multirow[b]{2}{*}{ University } & \multicolumn{3}{|c|}{ Ph.D. } & \multicolumn{3}{|c|}{ Masters (with thesis) } & \multicolumn{3}{|c|}{ Masters (non-thesis) } & \multirow[b]{2}{*}{ Total } \\
\hline & Male & Female & Total & Male & Female & Total & Male & Female & Total & \\
\hline $\begin{array}{l}\text { University of British Columbia } \\
\text { Faculty of Forestry }\end{array}$ & 49 & 23 & 72 & 62 & 53 & 115 & 12 & 0 & 1 & 188 \\
\hline $\begin{array}{l}\text { University of Northern British Columbia } \\
\text { Natural Resources and Environmental Studies }\end{array}$ & 5 & 4 & 9 & 33 & 32 & 65 & 5 & 5 & 10 & 84 \\
\hline $\begin{array}{l}\text { University of Alberta, Faculty of Agriculture, } \\
\text { Forestry and Home Economics } \\
\text { Department of Renewable Resources }\end{array}$ & 19 & 9 & 28 & 13 & 18 & 31 & 8 & 1 & 9 & 68 \\
\hline $\begin{array}{l}\text { Lakehead University } \\
\text { Faculty of Forestry and the Forest } \\
\text { Environment }\end{array}$ & 0 & 0 & 0 & 19 & 7 & 26 & 2 & 0 & 2 & 28 \\
\hline $\begin{array}{l}\text { University of Toronto } \\
\text { Faculty of Forestry }\end{array}$ & 31 & 14 & 45 & 9 & 10 & 19 & 4 & 11 & 15 & 79 \\
\hline $\begin{array}{l}\text { Université Laval } \\
\text { Faculté de Foresterie et géomatique }\end{array}$ & 60 & 22 & 82 & 56 & 33 & 89 & 16 & 13 & 26 & 197 \\
\hline $\begin{array}{l}\text { Université de Moncton } \\
\text { Faculté de foresterie }\end{array}$ & 0 & 0 & 0 & 6 & 2 & 8 & 0 & 0 & 0 & 8 \\
\hline $\begin{array}{l}\text { University of New Brunswick } \\
\text { Faculty of Forestry and } \\
\text { Environmental Management }\end{array}$ & 7 & 9 & 16 & 27 & 5 & 32 & 0 & 2 & 2 & 50 \\
\hline Totals & 171 & 81 & 252 & 225 & 160 & 385 & 36 & 29 & 65 & 702 \\
\hline
\end{tabular}

${ }^{1}$ Forestry broadly defined. Note the various names adopted by schools across Canada that host CFAB accredited undergraduate programs that are the approved basis for registered professional foresters.

${ }^{2}$ Undergraduate forestry program disbanded in 1996.

\footnotetext{
${ }^{1}$ Associate Dean, Graduate Studies and Research, Faculty of Forestry, The University of British Columbia, 2424 Main Mall, Vancouver, B.C. V6T $1 Z 4$. E-mail: mclean@interchg.ubc.ca
}

Key Words: forestry, Canadian universities, graduate programs, research funding 
Table 2. Summary of the Universities that received funding from the Sustainable Forest Management National Centre of Excellence (SFM-NCE) in 2001

\begin{tabular}{|c|c|}
\hline University & \$ Awarded \\
\hline Dalhousie University & $\$ 80800$ \\
\hline Université de Moncton & $\$ 35000$ \\
\hline University of New Brunswick ${ }^{1}$ & $\$ 95000$ \\
\hline Université du Québec à Rimouski & $\$ 36000$ \\
\hline Université du Québec à Chicoutimi & $\$ 25000$ \\
\hline Université Laval* & $\$ 107275$ \\
\hline Université du Québec à Trois-Rivières & $\$ 45350$ \\
\hline Université du Québec à Montréal & $\$ 530200$ \\
\hline Université de Montréal & $\$ 147870$ \\
\hline Concordia University & $\$ 23686$ \\
\hline McGill University & $\$ 150000$ \\
\hline University of Ottawa & $\$ 128000$ \\
\hline University of Toronto & $\$ 107000$ \\
\hline University of Guelph & $\$ 165000$ \\
\hline University of Western Ontario & $\$ 63000$ \\
\hline Lakehead University ${ }^{1}$ & $\$ 61000$ \\
\hline Lakehead University $^{2}$ & $\$ 135000$ \\
\hline University of Manitoba & $\$ 94800$ \\
\hline University of Winnipeg & $\$ 45000$ \\
\hline University of Saskatchewan & $\$ 25000$ \\
\hline University of Alberta ${ }^{1}$ & $\$ 742100$ \\
\hline University of Alberta $^{2}$ & $\$ 751500$ \\
\hline University of Calgary & $\$ 103500$ \\
\hline University of British Columbia $^{1}$ & $\$ 206000$ \\
\hline University of British Columbia ${ }^{2}$ & $\$ 170300$ \\
\hline Total & $\$ 4073381$ \\
\hline
\end{tabular}

in Forestry and Master of Forestry. Neither the University of Moncton nor Lakehead University offers Ph.D. programs in Forestry.

Ph.D. and Masters programs are offered at the other five AUFSC schools. In addition to the Ph.D. degree, the Faculty of Forestry and Environmental Management at the University of New Brunswick offers a Master of Science in Forestry, a Master of Science in Forest Engineering, a Master of Forestry and a Master of Forest Engineering; Laval University offers a Master of Science with thesis or a non-thesis essay option; the University of Toronto's Faculty of Forestry offers a Master of Science in Forestry and a Master of Forest Conservation; the University of Alberta's Faculty of Agriculture, Forestry and Home Economics offers a research Master of Science degree, a course work-based Master of Forestry and a combined MBA/MF degree; the University of Northern British Columbia's Faculty of Natural Resources and Environmental Studies offers Masters of Arts and Masters of Science degrees in Natural Resources and Environmental Studies; the University of British Columbia's Faculty of Forestry offers a Master of Forestry and Master of Applied Science in addition to their Master of Science degree. A total of 702 graduate students are registered in graduate programs in AUFSC faculties as of February 1, 2002 (Table 1). In the Masters programs overall, $42 \%$ are women while $36 \%$ of the Ph.D. students are women. Of the 702 students, $450(64 \%)$ are in masterate programs and $252(36 \%)$ are Ph.D. students. Overall, 65 of the Masters candidates are registered in non-thesis programs-a clear indication of the desire of today's foresters to upgrade their knowledge base.

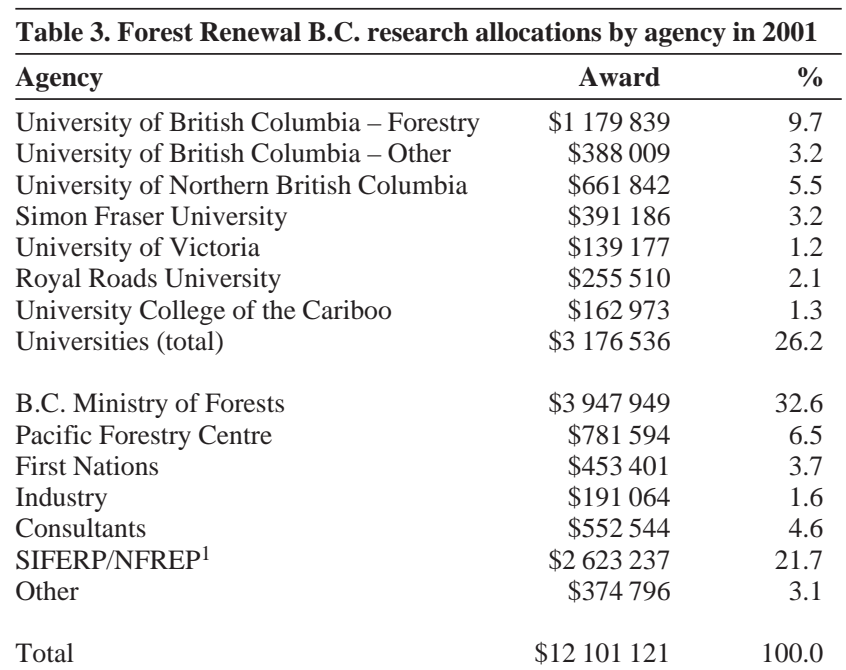

${ }^{1}$ SIFERP $=$ Southern Interior Forest Extension and Research Partnership; NFREP $=$ Northern Forest Research and Extension Partnership.

A major role in co-coordinating university research across Canada and across disciplines is being carried out by the Sustainable Forest Management of Canada's Forests National Centre of Excellence (SFM-NCE). The mission and research framework of this NCE has recently been described by Adamowicz et al. (2002). The AUFSC faculties represent only a portion of the university-based forestry research endeavours in Canada. A survey of the funding granted by the SFMNCE for 2001 showed that AUFSC schools received 32.4\% of the $\$ 4073.381$ awarded (Table 2). Twenty-two universities across the full breadth of Canada received funding from the network in 2001. Presently, 31 universities have submitted funding proposals for 2002 (G. Binsted, pers. com.).

There are also forest research funding programs in some provinces. In British Columbia, six provincial universities received 26.2\% of the $\$ 12101121$ research budget allocated by Forest Renewal B.C. in 2001 (Table 3). The recent change of government in B.C. is leading to a revision of forestry research support objectives in a new Forestry Investment Initiative. In Quebec, Le Fonds québécois de la recherche sur la nature et les technologies distributes research dollars to a wide variety of provincial research groups. Universities play an important role in the preparation of highly qualified personnel who will be the researchers and professors of tomorrow. Provincial and federal governments need to sustain their support for this critical enterprise if Canada is to maintain its leadership role in world forestry affairs.

\section{References}

Adamowicz, W.L., T.S. Veeman, G. Binsted, B. Macnab, D. Korber and A. Coyne. 2002. The Sustainable Forest Management Network: maintaining excellence and relevance in a changing world. For. Chron. 78(1): 112-114.

Dewhurst, S.M. and W.B. Kessler. 1999. Scenario planning: wading into the real world. J. For. 97(11): 43-47.

Luckai, N. 2002. Undergraduate programs offered by the university schools of forestry. For. Chron. 78(2): 240-244. 